\title{
The age of the Nantuo Formation and Nantuo glaciation in South China
}

\author{
Shihong Zhang, ${ }^{1}$ Ganqing Jiang ${ }^{2}$ and Yigui $\operatorname{Han}^{1}$ \\ ${ }^{1}$ State Key Laboratory of Geological Processes and Mineral Resources, China University of Geosciences, Beijing 100083, China; ${ }^{2}$ Department \\ of Geoscience, University of Nevada, Las Vegas, Nevada 89154-4010, USA
}

\begin{abstract}
A U-Pb sensitive high-resolution ion microprobe (SHRIMP) age of $654.5 \pm 3.8 \mathrm{Ma}$ from an ash bed immediately below the Nantuo Formation in South China provides the lowest age constraint for the Nantuo glaciation, which has been correlated with the global 'Marinoan' glaciation. A U-Pb SHRIMP age of $636.3 \pm 4.9 \mathrm{Ma}$ from a fallout tuff within the basal layer of the Nantuo Formation, along with the existing age of $635.2 \pm 0.6 \mathrm{Ma}$ from its overlying Doushantuo cap carbonate,
\end{abstract}

\begin{abstract}
suggests that the traditionally defined Nantuo Formation may have been deposited in a short time period at the end of the Nantuo glaciation. In combination with available ages globally, the data support a relatively short duration and rapid termination of 'Marinoan' glaciations.
\end{abstract}

Terra Nova, 20, 289-294, 2008

\section{Introduction}

The late Neoproterozoic is characterized by severe glaciations, with ice sheets extending to equatorial oceans (e.g. Sohl et al., 1999; Evans, 2000; Hoffman and Schrag, 2002). Although it has been generally accepted that there were at least three discrete Neoproterozoic ice ages, namely the Sturtian, Marinoan and Gaskiers glaciations, respectively (e.g. Bowring et al., 2003; Xiao et al., 2004; Halverson et al., 2005; Halverson, 2006), the nature and duration of these glaciations remain controversial (e.g. Hoffman and Schrag, 2002; Eyles and Januszczak, 2004; Kendall et al., 2006). Recent age dates and sedimentological studies suggested that the Sturtian glaciation may have lasted long from $c .750$ to $c .663 \mathrm{Ma}$ and its initiation and termination are globally diachronous, with potentially multiple episodes or a series of short-lived glaciations (e.g. Lund et al., 2003; Eyles and Januszczak, 2004; Fanning and Link, 2004; Zhou et al., 2004; Kendall et al., 2006; Rieu et al., 2006; Zheng et al., 2007). In contrast, the Gaskiers glaciation may have been regional and lasted less than 1 million years (Myr) around $582 \mathrm{Ma}$ (Bowring

Correspondence: Shihong Zhang, School of Earth Sciences and Resources, China University of Geosciences (Beijing), Beijing 100083, China. Tel.: + 86108232 2257; fax: +86 108232 2257; e-mail: shzhang@ cugb.edu.cn et al., 2003; Halverson et al., 2005; Halverson, 2006).

A more intriguing glaciation is the 'Marinoan'. Globally synchronous termination of Marinoan or inferred Marinoan glaciations envisioned in the 'snowball Earth' seems to be supported by the age of $635.5 \pm$ 1.2 Ma from the Ghaub diamictite in Namibia (Hoffmann et al., 2004) and the $635.2 \pm 0.6 \mathrm{Ma}$ age from the Doushantuo cap carbonate in South China (Condon et al., 2005). However, the initiation and duration of the Marinoan glaciations remain perhaps the most uncertain. Theoretical estimations suggest a > 5-Myr duration for the 'Marinoan' glaciation on the basis of thermal subsidence analysis (Hoffman et al., 1998; Halverson et al., 2002) and a 3-12 Myr duration on the iridium anomalies of cap carbonates (Bodiselitsch et al., 2005). Previous radiometric age data from South China roughly constrained the duration of the Marinoan-age Nantuo Formation as c. 663 to $c .635 \mathrm{Ma}$ (Zhou et al., 2004; Condon et al., 2005; Zhang et al., 2005). However, the older age of c. $663 \mathrm{Ma}$ was obtained from a tuffaceous bed immediately above the 'cap carbonate' of the Sturtian glacial diamictites, and thus it probably represents the termination age for the Sturtian glaciation rather than a constraint on the Marinoan age. In Australia, U-Pb SHRIMP age constraints for the inferred 'Marinoan' glacial successions in Tasmania suggested that some of the traditionally defined Marinoan- age diamictite may be significantly younger than c. $635 \mathrm{Ma}$ (Calver et al., 2004). Recent Re-Os date of $643 \pm$ 2.4 Ma from the Tindelpina Member in southern Australia, $>4 \mathrm{~km}$ below the Marinoan-age Elatina glacial diamictite, suggests that either the Marinoan glaciation lasted much less than $8 \mathrm{Myr}$ (c. 643 to $c .635 \mathrm{Ma}$ ) or the Elatina is younger than c. $635 \mathrm{Ma}$ (Kendall et al., 2006), although the reliability of Re-Os ages still needs to be tested by other dating methods.

The ubiquitous and persistent 'cap carbonates' overlying the Marinoanage diamictites have been used for a globally consistent chemical/oceanographic event that formed the basis for defining the Global Stratotype Section and Point (GSSP) of the Ediacaran Period (Knoll et al., 2004, 2006). However, uncertainties exist regarding the 'Marinoan' deglaciation and its transition to cap carbonate precipitation. Sedimentological and geochemical studies from Oman and Australia suggested multiple glacialinterglacial episodes (Allen et al., 2004; Eyles et al., 2007; Rieu et al., 2007), but well-developed cap carbonates are found only at the end of the ice age, suggesting that chemical/ oceanographic conditions did not reach the threshold for cap carbonate precipitation until the last phase of deglaciation. The presence of identical 'deep-water' cap carbonate facies across the platform-to-basin transects of the Yangtze platform in South China (Jiang et al., 2003a, 2006a,b) was used to infer a synchronous cap 
carbonate precipitation at least at a regional scale. In contrast, recent carbon isotope analyses in Namibia suggest that the basal Keilberg cap dolostone is diachronous at basinal scales, possibly tracking the sea-level rise during post-glacial transgression (Hoffman et al., 2007). Additional information on synchronous vs. diachronous post-glacial cap carbonate deposition is desirable for understanding the source of carbonate alkalinity and the chemical/oceanographic transition from deglaciation to cap carbonate precipitation.

In this article, we report new $\mathrm{U}-\mathrm{Pb}$ SHRIMP age data and stratigraphic observations from the Nantuo Formation in South China. The data constrain the Nantuo glaciation between $<654 \mathrm{Ma}$ and c. $635 \mathrm{Ma}$, but most of the traditionally defined 'Nantuo' glacial diamictite may have been deposited in a much shorter time period at the end of the glaciation.
The presence of a persistent 'boundary claystone' between the Nantuo glacial diamictite and its overlying Doushantuo cap carbonate across the basin suggests a time lag between deglaciation and cap carbonate precipitation.

\section{The Nantuo Formation in South China}

The Neoproterozoic strata in South China were deposited in a rift to passive margin along the southeastern side of the Yangtze Block (Fig. 1a,b; Li et al., 1999; Jiang et al., 2003b) and are composed of three major parts (Fig. 1c; Jiang et al., 2003b; Zhou et al., 2004): (1) the pre-glacial siliciclastic rocks (Liantuo Formation and Banxi Group) that are thin $(<500 \mathrm{~m})$ in the interior of the Yangtze Block and thick $(>2 \mathrm{~km})$ in the basin, (2) two Cryogenian glacial diamictite intervals (Chang'an/Dongshanfeng/
Tiesi'ao Formations and Nantuo Formation) separated by a manganesebearing siltstone/shale unit (Datangpo/Xiangmeng Formations) that also display a thickening trend towards the basin (Fig. 1d), and (3) post-glacial marine carbonates and shales (Doushantuo and Dengying/ Liuchapo Formations) that are thick $(>700 \mathrm{~m})$ in the shelf but thin $(<250 \mathrm{~m})$ in the basin.

As the younger of the two glaciogenic units, the Nantuo Formation rests unconformably on the interglacial Datangpo/Xiangmeng Formation (Fig. 1d,e). Its thickness varies from 60 to $130 \mathrm{~m}$ in the shelf (sections 1-9; Fig. 1d) and to $>500 \mathrm{~m}$ in the basin (sections 10 and 11; Fig. 1d). Lithologically, the Nantuo Formation includes massive and stratified diamictites and thin conglomerate, sandstone and siltstone beds (Jiang et al., 1996). Abundant bullet-shaped and striated clasts, dropstones, and lonestones
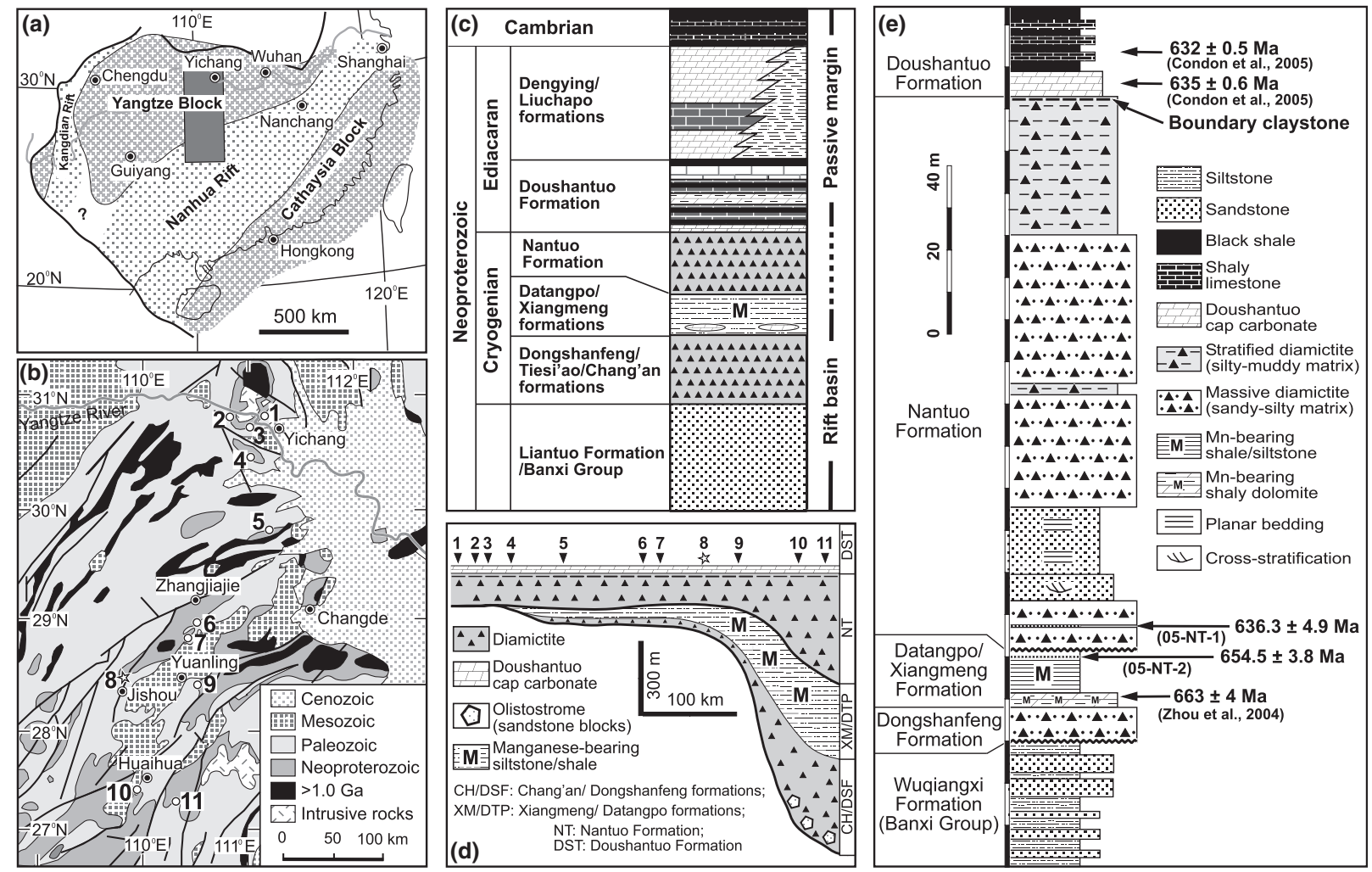

Fig. 1 (a) Neoproterozoic tectonic framework for South China, emphasizing inferred continental rift systems at c. $800 \mathrm{Ma}$ (modified from Li et al., 1999; Jiang et al., 2003a). (b) Simplified geological map of study area and measured sections used to construct Fig. 1d. (c) Simplified stratigraphic column for the Neoproterozoic strata in South China. (d) Simplified stratigraphic cross-section for the Cryogenian strata. (e) Measured section in Maopingdong, western Hunan (location 8 in b and d marked by the star) showing stratigraphic levels of dated ash and tuffaceous beds, and ages reported by Zhou et al. (2004), Condon et al. (2005) and from equivalent sections. 
confirm their glacial origin (Dobrzinski and Bahlburg, 2007).

The Nantuo Formation is conformably overlain by a 5 -m-thick Doushantuo cap carbonate that is composed of laminated dolostone and dolomitic limestone, with localized, but widespread occurrence of cavities, sheet cracks, tepee-like structures at the basal level (Jiang et al., 2006a). Similar to the other 'Marinoan' age cap carbonates globally, the Doushantuo cap carbonate yielded a negative carbon isotope excursion with average $\delta^{13} \mathrm{C}_{\text {carb }}$ values as low as $-5 \%$ (VPDB; Jiang et al., 2003a, 2006a,b).

\section{New age data}

The sampled section is located at Maopingdong, near the Jishou city in western Hunan (section 8 in Fig. 1b,d; N283․ $301^{\prime}$, E10953.683'). The Nantuo Formation in this locality is $130 \mathrm{~m}$ thick and rests unconformably on the 13-m-thick, interglacial Datangpo Formation (Fig. 1e). Two samples were collected for age dating: an ash bed from the top of the Datangpo Formation (05-NT-2; $0.6 \mathrm{~m}$ below the Nantuo glacial diamictite) and a tuffaceous bed from the basal Nantuo Formation, $4.8 \mathrm{~m}$ above the Nantuo/Datangpo boundary (05-NT-1; Fig. 1e). The U, $\mathrm{Th}$ and $\mathrm{Pb}$ isotope compositions were analysed using SHRIMP II at Beijing Ion Microprobe Analysis Center, Chinese Academy of Geological Sciences, following the procedures described in Williams (1998). The data table and a detailed description are provided in the electronic appendix.

The ash bed (05-NT-2) immediately below the Nantuo Formation is $3 \mathrm{~cm}$ thick, yellowish green and composed of albite, quartz, K-feldspar, and illite-montmorillonite. Platy and cuspate glass shards were observed, indicating its contemporaneous volcanic origin. Zircon grains separated from this sample are euhedral, 50-100 $\mu \mathrm{m}$ long, with well-developed oscillatory zonation (Fig. A1 in appendix). Analyses of 19 zircons from this sample (Table A1 in appendix) yielded a weighted-mean ${ }^{206} \mathrm{~Pb} /{ }^{238} \mathrm{U}$ date of $654.5 \pm 3.8 \mathrm{Ma}$, with mean square of weighted deviates (MSWD) of 0.71 (Fig. 2).

The greenish grey tuffaceous bed (05-NT-1) within the basal Nantuo Formation is $0-5 \mathrm{~cm}$ thick and pinches

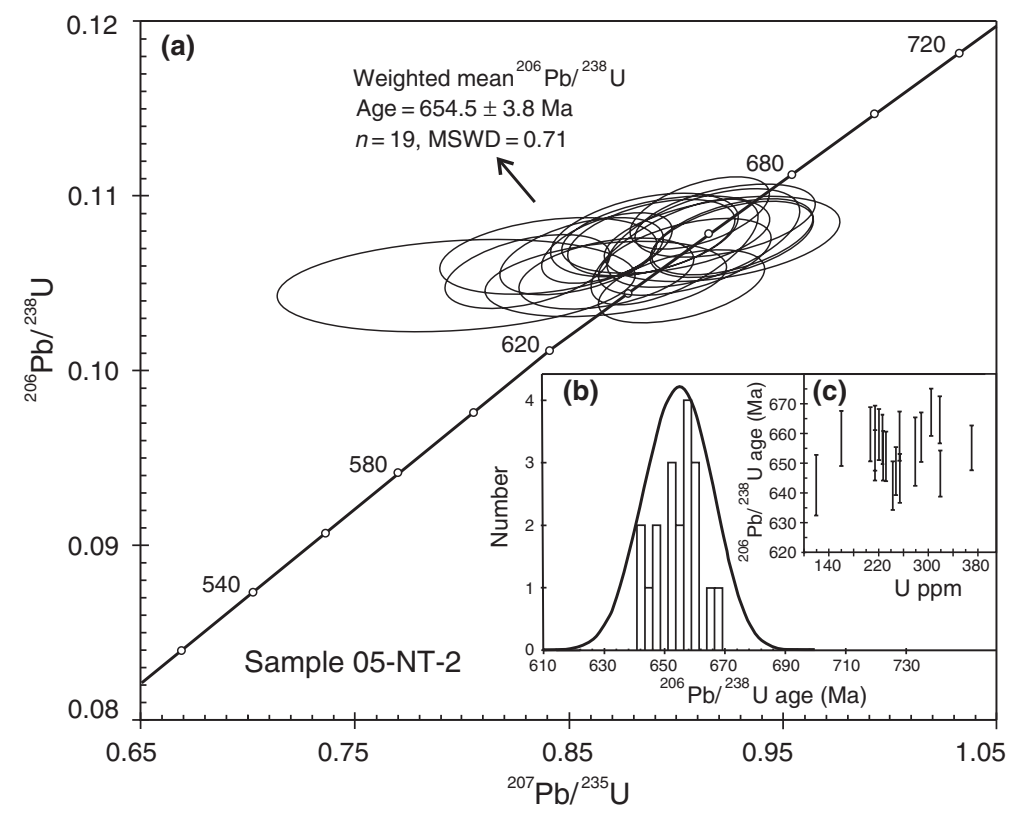

Fig. $2 \mathrm{U}-\mathrm{Pb}$ data for zircon grains from sample 05-NT-2, $0.6 \mathrm{~m}$ below the Nantuo Formation glacial diamictite. (a) U-Pb Concordia plot for the 19 analysed zircon grains; (b) cumulative probability plot showing the distribution of ${ }^{206} \mathrm{~Pb} /{ }^{238} \mathrm{U}$ date, with a peak of $654 \pm 3.8 \mathrm{Ma}$; (c) ${ }^{206} \mathrm{~Pb} /{ }^{238} \mathrm{U}$ date $-\mathrm{U}$ concentration plot. Analyses with $1 \sigma$ error ellipses are plotted as radiogenic ratios after common $\mathrm{Pb}$ correction, using measured ${ }^{204} \mathrm{~Pb}$. Weighted-mean ${ }^{206} \mathrm{~Pb}^{238} \mathrm{U}$ dates at a $95 \%$ confidence level for the main group of zircon grains show the best estimated age for the dated sample. MSWD - mean square of weighted deviates.

out along strike due to erosion from overlying diamictite. Petrographically, it is mainly composed of illite, with subordinate silty quartz grains. This bed was probably formed as suspension fallout in a shallow marine environment and was partially removed by overlying glacial debris flows (e.g. Fanning and Link, 2004). Zircon grains separated from this sample are subeuhedral to euhedral and $50-150 \mu \mathrm{m}$ in size (Fig. A2 in appendix). Twentythree grains were analysed (Table A2 in appendix). Most $\mathrm{U}-\mathrm{Pb}$ dates of the analysed zircon grains are within error of concordia after the common $\mathrm{Pb}$ correction (Fig. 3a). Cumulative probability analysis of ${ }^{206} \mathrm{~Pb} /{ }^{238} \mathrm{U}$ dates identified a distinguishable population around $635 \mathrm{Ma}$ (Fig. 3b), with 12 zircon grains yielding a weighted-mean ${ }^{206} \mathrm{~Pb} /{ }^{238} \mathrm{U}$ date of $636.3 \pm 4.9 \mathrm{Ma}$ $(\mathrm{MSWD}=1.06)$. Another population with 9 zircon grains has the weightedmean ${ }^{206} \mathrm{~Pb} /{ }^{238} \mathrm{U}$ date of $664.9 \pm$ $5.6 \mathrm{Ma}(\mathrm{MSWD}=0.33)$. This date is older than that of sample 05-NT-2 (Fig. 2) from the same section, but is indistinguishable with the age of $663 \pm 4$ Ma reported from the basal
Datangpo Formation (Zhou et al., 2004). We thus interpret that the older population has a detrital origin. Because of the minor overlap of the two date groups in this sample (Fig. 3a), we cannot preclude the possibility that the younger date resulted from the $\mathrm{Pb}$ loss of the older population. However, the lack of metamorphism and deformation in the sampled section and the concordance of data points (Fig. 3a) favour an interpretation that the younger date $(636.3 \pm$ $4.9 \mathrm{Ma}$ ) is the closest to the depositional age.

\section{Discussion}

\section{The age of the Nantuo glaciation}

SHRIMP U-Pb zircon data presented here document that the Nantuo glaciation in South China is not older than $654.5 \pm 3.8 \mathrm{Ma}$. This is consistent with the age of $663 \pm 4 \mathrm{Ma}$ from the basal Datangpo Formation that marked the end of the Sturtian glaciation in South China (Zhou et al., 2004). However, considering the erosion/non-deposition below the basal 


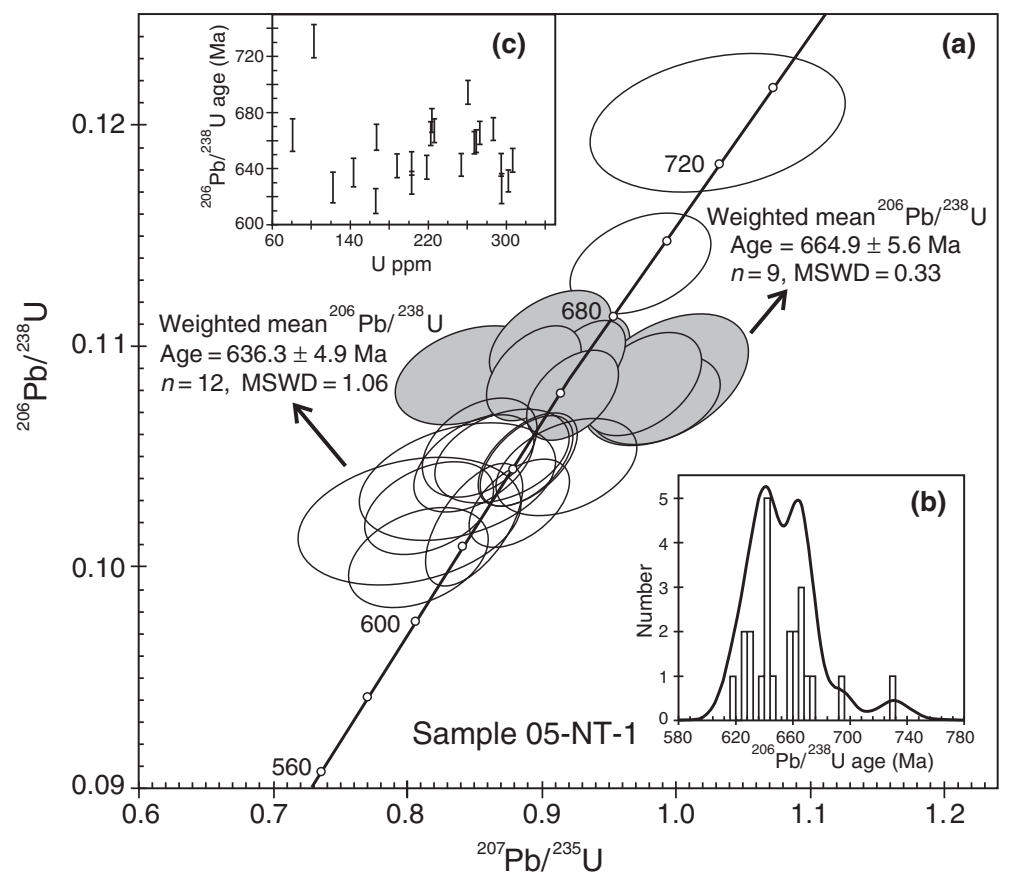

Fig. $3 \mathrm{U}-\mathrm{Pb}$ data for zircon grains from sample 05-NT-01, $4.8 \mathrm{~m}$ above the Nantuo/Daotangpo contact. (a) U-Pb Concordia plot for the 23 analyses, with the weighted-mean ${ }^{206} \mathrm{~Pb} /{ }^{238} \mathrm{U}$ date for each zircon group, which are interpreted as different origins (see text); (b) cumulative probability plot showing the ${ }^{206} \mathrm{~Pb} /{ }^{238} \mathrm{U}$ date peaks around $635 \mathrm{Ma}$ and $665 \mathrm{Ma}$; (c) variation in ${ }^{206} \mathrm{~Pb} /{ }^{238} \mathrm{U}$ date with uranium concentration. Analyses with $1 \sigma$ error ellipses are plotted as radiogenic ratios after common $\mathrm{Pb}$ correction, using measured ${ }^{204} \mathrm{~Pb}$. Weighted-mean ${ }^{206} \mathrm{~Pb}^{238} \mathrm{U}$ date at a $95 \%$ confidence level for the main group of zircons show the best estimated age for the dated sample. MSWD - mean square of weighted deviates.
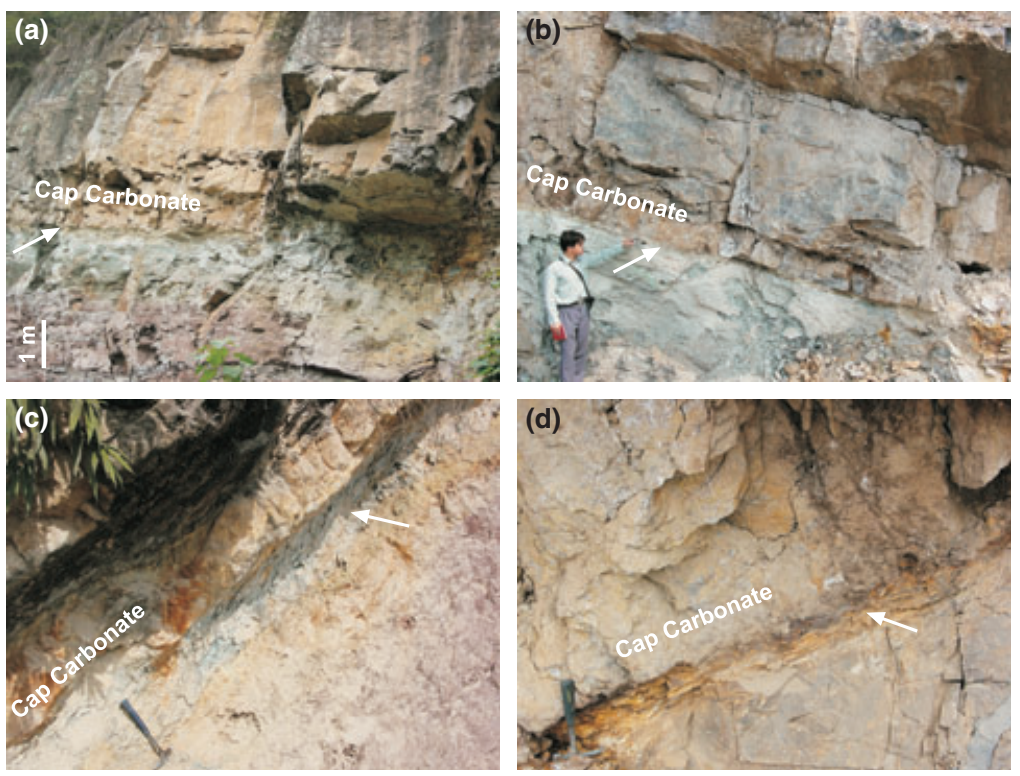

Fig. 4 Field photos of the boundary claystone between the topmost Nantuo Formation and overlying cap carbonate. (a) Liantuo section (loc. 3 in Fig. 1b,d); (b) Huajipo section (loc. 4 in Fig. 1b,d); (c) Duoding section (Guizhou province, $750 \mathrm{~km}$ southwest of the Yangtze Gorges); (d) Yuanjia section in Huaihua (loc. 11 in Fig. 1b,d).
Nantuo Formation, which is consistent with the minor thickness $(13 \mathrm{~m})$ of the Datangpo Formation in the dated section (compared to the maximum thickness of $250 \mathrm{~m}$ for the Datangpo Formation in South China), the beginning of the Nantuo glaciation may be significantly younger than $654 \mathrm{Ma}$. This is consistent with the $<643.2 \pm$ 2.4 Ma age obtained for the Elatina glaciation in Australia (Kendall et al., 2006). If the Nantuo glaciation is equivalent to the Elatina glaciation in Australia, its duration would be less than $8 \mathrm{Myr}$ from $<643 \mathrm{Ma}$ to $c$. $635 \mathrm{Ma}$ (Condon et al., 2005). To confirm this prediction, however, requires a careful search of dateable minerals in the basinal facies of the Nantuo Formation (section 10 and southward in Fig. 1b,d).

\section{The age of the Nantuo Formation}

The age of $636 \pm 4.9 \mathrm{Ma}$ from the basal Nantuo Formation, in combination with the $635.2 \pm$ 0.6 Ma age from the overlying Doushantuo cap carbonate (Condon et al., 2005), suggests that the typical Nantuo Formation in the continental shelf of the Yangtze platform (where the type section of this unit was defined) may have been deposited in a short time period at the end of the Nantuo glaciation. The current data, however, bear considerable uncertainties on exactly how long that had taken. Considering the uncertainties of the SHRIMP dating method, this time period could be anywhere from 0 to 6 Myr. Nonetheless, the current data are consistent with the $635.5 \pm$ 1.2 Ma age from diamictites of the Ghaub Formation in Namibia where the ash bed is located $\sim 30 \mathrm{~m}$ below the Keilberg cap dolostone (Hoffmann et al., 2004). Together they support a rapid termination of 'Marinoan' glaciations.

Considering the shelf setting of the dated section, two predictions need to be tested in the basinal facies of the Nantuo Formation. One possibility is that the shelf facies of the Nantuo Formation is entirely recessional (e.g. Hoffman, 2005) and time equivalent to the last deglacial phase in the basin. In this case, continental ice sheets may have covered the shelf area and glacial advance and retreat before the final deglaciation may have been limited to 
the shelf margins. Such a scenario would imply that the basal Nantuo Formation in the basin would have a significantly older age than c. $636 \mathrm{Ma}$, but not older than $654 \mathrm{Ma}$ (or $643 \mathrm{Ma}$ if the Re-Os date from Australia is considered). An alternative scenario could be that the shelf and basinal Nantuo Formation may all record deposits from a rapid deglaciation at the end of the Nantuo glaciation. In this case, the glacial-non-glacial sedimentary cycles in the Nantuo Formation (e.g. Jiang et al., 1996; Dobrzinski and Bahlburg, 2007) may record short-term cycles during the Nantuo deglaciation.

\section{Deglaciation and cap carbonate precipitation}

A rather intriguing phenomenon observed in this study is the persistent occurrence of an 8 to $20 \mathrm{~cm}$ thick 'boundary claystone' between the topmost Nantuo Formation and its overlying cap carbonate (Fig. 4). The greenish gray claystone shows a transitional relationship with the underlying stratified diamictite, but a sharp contact with the cap carbonate. It occurs in most measured sections across the shelf-to-basin transect (Fig. 1d) and other sections in Guizhou, including places where the entire Nantuo Formation is only $6 \mathrm{~m}$ thick (e.g. Duoding section Fig. 4c). Petrographically, the claystone is composed mainly of illite and kaolinite, with 10-20\% silty quartz grains. In some sections (e.g. Fig. 4d), euhedral pyrite grains of $100-300 \mu \mathrm{m}$ in size are present as thin laminae within the claystone.

The presence of such a claystone between the diamictite and the overlying cap carbonate (Fig. 4) across the $>500 \mathrm{~km}$ transects of the Yangtze platform points to a time lag between the end of the Nantuo deglaciation and cap carbonate precipitation, although the duration of the lag is hard to be constrained. This boundary claystone contains zircon grains that produced ages exclusively of $c .750$ to c. $800 \mathrm{Ma}$ (S. Bowring, personal communications, 2004), precluding syndepositional volcanic origin but fallout deposition from suspension. It suggests that cap carbonate deposition in South China may have not started until ice sheets disappeared in the Yangtze platform and a threshold condition (e.g. carbonate supersaturation) was reached after deglaciation.

\section{Acknowledgements}

We thank Huaichun Wu and Jin Dong for field assistance and Song Biao for SHRIMP analyses. We thank Profs. Hartwig Frimmel, Paul Hoffman and an anonymous reviewer for constructive reviews. Comments and suggestions from the associate editor and journal editor (Prof. Max Coleman) and Prof. Nicholas Christie-Blick are greatly appreciated. This research was supported by grants from the National Natural Science Foundation of China (40572019, 40621002), projects of Ministry of Education of China (NCET-04-0727, IRT0546, '111' project B07011) and the UNLV research funds.

\section{References}

Allen, P.A., Leather, J. and Brasier, M.D., 2004. The Neoproterozoic Fiq glaciation and its aftermath, Huqf supergroup of Oman. Basin Res., 16, 507-534.

Bodiselitsch, B., Koeberl, C., Master, S. and Reimold, W.U., 2005. Estimating duration and intensity of Neoproterozoic snowball glaciations from Ir anomalies. Science, 308, 239-242.

Bowring, S.A., Myrow, P.M., Landing, E., Ramezani, J. and Grotzinger, J.P., 2003. Geochronological constraints on terminal Proterozoic events and the rise of metazoans. Geophys. Res. Abstr. (EGS, Nice), 5, 13,219.

Calver, C.R., Black, L.P., Everard, J.L. and Seymour, D.B., 2004. U-Pb zircon age constraints on late Neoproterozoic glaciation in Tasmania. Geology, 32, 893-896.

Condon, D., Zhu, M., Bowring, S., Wang, W., Yang, A. and Jin, Y., 2005. U-Pb ages from the Neoproterozoic Doushantuo Formation, China. Science, 308, 95-98.

Dobrzinski, N. and Bahlburg, H., 2007. Sedimentology and environmental significance of the Cryogenian successions of the Yangtze platform, South China block. Palaeogeogr. Palaeoclimatol. Palaeoecol., 254, 100-122.

Evans, D.A.D., 2000. Stratigraphic, geochronological, and paleomagnetic constraints upon the Neoproterozoic climatic paradox. Am. J. Sci., 300, 347-433.

Eyles, N. and Januszczak, N., 2004. 'Zipper-rift': a tectonic model for Neoproterozoic glaciations during the breakup of Rodinia after 750 Ma. EarthSci. Rev., 65, 1-73.

Eyles, C.H., Eyles, N. and Grey, K., 2007. Palaeoclimate implications from deep drilling of Neoproterozoic strata in the Officer Basin and Adelaide Rift Complex of Australia; a marine record of wet-based glaciers. Palaeogeogr. Palaeoclimatol. Palaeoecol., 248, 291-312.

Fanning, C.M. and Link, P.K., 2004. U-Pb SHRIMP ages of Neoproterozoic (Sturtian) glaciogenic Pocatello Formation, southeastern Idaho. Geology, 32, 881-884.

Halverson, G.P., 2006. A Neoproterozoic chronology. In: Neoproterozoic Geobiology and Paleobiology (S. Xiao and A.J. Kaufman, eds), pp. 232-272. Dordrecht: Springer-Verlag.

Halverson, G.P., Hoffman, P.F., Schrag, D.P. and Kaufman, J.A., 2002. A major perturbation of the carbon cycle before the Ghaub glaciation (Neoproterozoic) in Namibia: prelude to snowball earth? Geophys. Geochem. Geosystems, 3, 16. Doi: 10.1029/2001GC000244.

Halverson, G.P., Hoffman, P.F., Schrag, D.P., Maloof, A.C. and Rice, A.H.N., 2005. Toward a Neoproterozoic composite carbon-isotope record. Geol. Soc. Am. Bull., 117, 1181-1207.

Hoffman, P.F., 2005. On Cryogenian (Neoproterozoic) ice-sheet dynamics and the limitations of the glacial sedimentary record. S. Afr. J. Geol., 108, 557-577.

Hoffman, P.F. and Schrag, D.P., 2002. The snowball Earth hypothesis: testing the limits of global change. Terra Nova, 14, 129-155.

Hoffman, P.F., Kaufman, A.J., Halverson, G.P. and Schrag, D.P., 1998. A Neoproterozoic snowball earth. Science, 281, 1342-1346.

Hoffman, P.F., Halverson, G.P., Domack, E.W., Husson, J.M., Higgins, J.A. and Schrag, D.P., 2007. Are basal Ediacaran (635 Ma) post-glacial "cap dolostones" diachronous? Earth Planet. Sci. Lett., 258, 114-131.

Hoffmann, K.-H., Condon, D.J., Bowring, S.A. and Crowley, J.L., 2004. U-Pb zircon date from the Neoproterozoic Ghaub Formation, Namibia: constraints on Marinoan glaciation. Geology, 32, 817-820.

Jiang, G., Wang, Z. and Zhang, L., 1996. Sequence stratigraphy of upper Proterozoic glacigenic rocks in southeastern margin of Yangtze Platform. J. China Univ. Geosci., 7, 38-45.

Jiang, G., Kennedy, M.J. and ChristieBlick, N., 2003a. Stable isotopic evidence for methane seeps in Neoproterozoic postglacial cap carbonates. Nature, $\mathbf{4 2 6}$, 822-826.

Jiang, G., Sohl, L.E. and Christie-Blick, N., 2003b. Neoproterozoic stratigraphic comparison of the Lesser Himalaya (India) and Yangtze Block (South China); paleogeographic implications. Geology, 31, 917-920.

Jiang, G., Kennedy, M.J., Christie-Blick, N., Wu, H. and Zhang, S., 2006a. Stratigraphy, sedimentary structures, and textures of the late Neoproterozoic 
Doushantuo cap carbonate in South China. J. Sed. Res., 76, 978-995.

Jiang, G., Shi, X. and Zhang, S., 2006b.

Methane seeps, methane hydrate destabilization, and the late Neoproterozoic postglacial cap carbonates. Chin. Sci. Bull., 51, 1152-1173.

Kendall, B., Creaser, R.A. and Selby, D., 2006. Re-Os geochronology of postglacial black shales in Australia: constraints on the timing of "Sturtian" glaciation. Geology, 34, 729-732.

Knoll, A.H., Walter, M.R., Narbonne, G.M. and Christie-Blick, N., 2004. A new period for the geologic time scale. Science, 305, 621-622.

Knoll, A.H., Walter, M.R., Narbonne, G.M. and Christie-Blick, N., 2006. The Ediacaran period: a new addition to the geologic time scale. Lethaia, 39, 13-20.

Li, Z.X., Li, X.H., Kinny, P.D. and Wang, J., 1999. The breakup of Rodinia: did it start with a mantle plume beneath South China? Earth Planet. Sci. Lett., 173, 171181.

Lund, K., Aleinikoff, J.N., Evans, K.V. and Fanning, C.M., 2003. SHRIMP $\mathrm{U}-\mathrm{Pb}$ geochronology of Neoproterozoic Windermere Supergroup, central Idaho: implications for rifting of western Laurentia and synchroneity of Sturtian glacial deposits. Geol. Soc. Am. Bull., 115, 349-372.

Rieu, R., Allen, P.A., Etienne, J.L., Cozzi, A. and Wiechert, U., 2006. A Neoproterozoic glacially influenced basin margin succession and 'atypical' cap carbonate associated with bedrock palaeovalleys, Mirbat area, southern Oman. Basin Res., 18, 471-496.

Rieu, R., Allen, P.A., Plotze, M. and Pettke, T., 2007. Climatic cycles during a Neoproterozoic "snowball" glacial epoch. Geology, 35, 299-302.

Sohl, L.E., Christie-Blick, N. and Kent, D.V., 1999. Paleomagnetic polarity reversals in Marinoan (ca. $600 \mathrm{Ma}$ ) glacial deposits of Australia: implications for the duration of low-latitude glaciation in Neoproterozoic time. Geol. Soc. Am. Bull., 111, 1120-1139.
Williams, I.S., 1998. U-Th-Pb geochronology by ion microprobe. In: Applications of Microanalytical Techniques to Understanding Mineralizing Processes (M.A. McKibben, W.C. Shanks, W.I. Ridley, eds). Rev. Econ. Geol., 7, 1-35.

Xiao, S., Bao, H., Wang, H., Kaufman, A.J., Zhou, C., Li, G., Yuan, X. and Ling, H., 2004. The Neoproterozoic Quruqtagh Group in eastern Chinese Tianshan: evidence for a post-Marinoan glaciation. Precambrian Res., 130, 1-26.

Zhang, S., Jiang, G., Zhang, J., Song, B., Kennedy, M.J. and Christie-Blick, N., 2005. U-Pb sensitive high-resolution ion microprobe ages from the Doushantuo Formation in south China: Constraints on late Neoproterozoic glaciations. Geology, 33, 473-476.

Zheng, Y.-F., Wu, Y.-B., Gong, B., Chen, R.-X., Tang, J. and Zhao, Z.-F., 2007. Tectonic driving of Neoproterozoic glaciations: evidence from extreme oxygen isotope signature of meteoric water in granite. Earth Planet. Sci. Lett., 256, 196-210.

Zhou, C., Tucker, R., Xiao, S., Peng, Z., Yuan, X. and Chen, Z., 2004. New constraints on the ages of Neoproterozoic glaciations in south China. Geology, 32, 437-440.

Received 5 November 2007; revised version accepted 19 April 2008

\section{Supplementary Material}

The following material is available at http://www.blackwellpublishing. com/products/journals/suppmat/TER/ TER819/TER819sm.htm:

Figure A1. Pairs of transmitted and reflected-light photomicrographics and CL image (with white circles) of dated zircons from the top of Datangpo Formation, sample number 05-NT-02. Circles show the positions and sizes of the SHRIMP beam spots.
Figure A2. Pairs of transmitted and reflected-light photomicrographics and CL image (with white circles) of dated zircons from the basal Nantuo Formation, sample number 05-NT-01. Circles show the position and size of the SHRIMP beam spots. (A) Zircons with the group age of $636.3 \pm 4.9$ Ma; (2) Zircons with the group age of $664.9 \pm 5.6 \mathrm{Ma}$.

Figure A3. Summary plot of the age data (Table A1) obtained from the ash bed on the top of the Datangpo Formation, sample 05-NT-2. (A) $\mathrm{U}-\mathrm{Pb}$ Concordia plot for the 19 analyzed zircon grains; (B) Cumulative Probability plot showing the distribution of ${ }^{206} \mathrm{~Pb} /{ }^{238} \mathrm{U}$ date, with a peak of $654 \pm 3.8 \mathrm{Ma}$; (C) ${ }^{206} \mathrm{~Pb} /{ }^{238} \mathrm{U}$ date $\mathrm{U}$ concentration plot.

Figure A4. Summary plot of the age data (Table A2) obtained from the ash bed from the basal Nantuo Formation, sample 05-NT-01. (A) $\mathrm{U}-\mathrm{Pb}$ Concordia plot for the 23 analyses, with the weighted-mean ${ }^{206} \mathrm{~Pb} /{ }^{238} \mathrm{U}$ date for each zircon group, which are interpreted as different origins (see comment); (B) Cumulative Probability plot showing the ${ }^{206} \mathrm{~Pb} /{ }^{238} \mathrm{U}$ date peaks around $635 \mathrm{Ma}$ and $665 \mathrm{Ma}$; (C) Variation of ${ }^{206} \mathrm{~Pb} /{ }^{238} \mathrm{U}$ date with uranium concentration.

Table A1. Summary of SHRIMP U-Pb zircon data for Sample 05-NT-2.

Table A2. Summary of SHRIMP $\mathrm{U}-\mathrm{Pb}$ zircon data for Sample 05-NT-1.

Please note: Blackwell Publishing are not responsible for the content or functionality of any supplementary materials supplied by the authors. Any queries (other than missing material) should be directed to the corresponding author for the article. 